\title{
Columbus in the Twilight Zone: Bruce Ackerman's "Discovery" of the Constitution
}

\section{Jonathan Simon}

Bruce Ackerman, We the People: Foundations. Cambridge, Mass.: Harvard University Press, Belknap Press, 1991. Pp. 369. \$24.95.

If Bruce Ackerman is right, the most contentious issues of modern constitutional theory have been fought out on a map that misses the most significant features of our political landscape. For the last decade constitutional theorists have hotly debated whether the U.S. Constitution is best understood through one or the other of an amazing variety of philosophical traditions including Lockean liberalism, Kantean ethics, hermeneutic theory, and the Atlantic Republican tradition. On Ackerman's account these theorists have failed to appreciate the uniquely American innovations in democratic theory and practice, as they strived mightily to fit them into the glass slipper of European political theory. In We the People, and two more promised volumes, Ackerman sets out to redescribe our constitutional past and reinterpret our present impasses in light of his discovery of America's great invention in 1787-“dualist democracy."

Like Columbus's "discovery" of America, the five hundredth anniversary of which is being celebrated and critiqued this year, Ackerman's self-pronounced "discovery" of the Constitution raises troubling questions. How do we come to grips with our dependence on a past we cannot help but reshape by rethinking? How can we escape the reproduction of the processes of domination that marked the past? To his great credit Ackerman wrestles with these problems.

The continent he claims for us is empowering in its rediscovered

Jonathan Simon is Assistant Professor, Department of Political Science, University of Michigan, and Visiting Associate Professor of Law, University of Miami, 1992-93. 
sources of self-government. At the same time, like Columbus, Ackerman is too blinded by his expectations to truly recognize the territory he has landed upon. His reconstruction of American constitutional history turns away from the powerful antidemocratic forces that have shaped our destiny and in affirming that heritage uncritically leaves us vulnerable to accepting as willed what has in fact been imposed on "we the people."

In 1992 terms like "discovery" seem not only suspiciously imperial but downright silly. The rapid pace of Ackerman's tour of the past and his exuberant authorial voice often has more of the feel of a P. T. Barnum "attraction" than a history museum. But the strongest testament one can make about this book is that its enlightening and provocative insights overcome the hucksterish tone of the narrative. Whatever its flaws, We the People has provided a mapping of our constitutional history that is certain to alter the way we argue about that history. Moreover, it is a map which, freed of the imperial epistemological claims of its author, may provide a powerful source for reinvigorating not only academic debate but our constitutional politics.

For those who follow constitutional theory debates this book has been long awaited. Over the last decade Ackerman has deposited tantalizing sections of the story in a series of important law review articles. ${ }^{1}$ Confronting the complete picture is exhilarating for its sheer breadth and explanatory reach. There are good reasons to be suspicious of master paradigms in American politic. There is also much to be gained from efforts like Ackerman's. They may not yield us a "normal science,"2 but they can provoke new questions, new researches, new controversies that a thousand less ambitious projects will not yield.

So what do we see when we look out over our constitutional history from Ackerman's vantage? In part it is familiar. The framing of the Constitution and its ratification are prominent, as is Reconstruction (1863-77), the "Lochner era" of judicial restriction on economic regulation (1886-1934), and its eventual demise at the hands of Roosevelt's New Deal (1937). Yet as in an episode of "The Twilight Zone" familiar landscapes are disturbingly different in Ackerman's America. Reconstruction and the New Deal stand out not as adjustments in the framework hammered out in Philadelphia but as re-foundations. American political development, which has so often been praised for its stability, looks suddenly more like France, with its series of Republics separated by near-revolutionary breaks. While Ackerman detects no American equivalents to the empires and res-

1. Bruce Ackerman, "The Storrs Lectures: Discovering the Constitution," 93 Yale LJ. 1013 (1984); id., "Transformative Appointments," 101 Harv. L. Rev. 1164 (1988); id., "Constitutional Law/Constitutional Politics," 99 Yale LJ. 453 (1989).

2. Thomas Kuhn, The Structure of Scientific Revolutions (Chicago: University of Chicago Press, 1962). 
torations of France, his Republics are separated by profound ruptures he calls "constitutional moments."

Of course, there is a mechanism in the Constitution to deal with political change. The 1787 Constitution provides formal procedures for amendment in article V. Proposals for amendment may begin in Congress, where if they receive a super majority of three-quarters they are sent to the states for consideration either in the legislatures or in specially called conventions. They may also begin in the state legislatures and move from there to Congress. On Ackerman's account these procedures are only a particular version of what he discerns as a deeper structural set of requirements for constitutional change in the American system. Article $\mathrm{V}$, after all, was put in place by men who ignored the relevant formal amendment procedures for the Articles of Confederation, and according to Ackerman later constitutional reformers have ignored article V's formal requirements.

The Reconstruction amendments which profoundly altered American political life superficially fit the article $\mathrm{V}$ format; they were adopted by the requisite two-thirds of the sitting members of both houses of Congress and ratified by three-quarters of the states deemed eligible to vote. Yet on closer inspection they are strikingly different. By requiring that threequarters of the states agree to any amendment, the framers of article $\mathrm{V}$ gave a minority of states a veto over any fundamental change in the national compact. When the powerful Republican leaders of Congress forced the southern states to sign the Fourteenth Amendment as a condition for the restoration to representation in the national government, they clearly trampled the spirit if not the letter of that minority veto.

Things changed even more dramatically in the 1930s when, according to Ackerman, President Roosevelt accomplished a third constitutional refounding. This New Deal moment was achieved through a prolonged and bitter struggle with a conservative Supreme Court and given its mandate not by ratification assemblies but by an electoral landslide for FDR in the 1936 election. No formal amendments mark this moment at all, only a series of pivotal Supreme Court decisions renouncing their former resistance to the welfare state. This potent exchange between a charismatic president and a Supreme Court resistant to demands for change has become a modern model for constitutional change, replacing the article $\mathrm{V}$ system. ${ }^{3}$

Here Ackerman is charting not Rod Serling's "Twilight Zone," but Justice Jackson's "zone of twilight." In his famous concurring opinion in

3. This does not mean that article $V$ is not used to formally amend the Constitution, as it has been five times since the New Deal. Not every constitutional amendment is a "constitutional moment" in Ackerman's sense, only those efforts at constitutional change that seek to work a fundamental rearrangement of the constitutional order. 
Youngstoun Sheet $\mathcal{E}$ Tube Co. v. Sawyer (the Steel Seizure Case), Justice Jackson suggested that the separation of powers allowed a process of political evolution in which American political institutions struggled to define roles that had no clear constitutional specifications. ${ }^{4}$ Ackerman goes further in suggesting specific stages of that evolution and a set of informal standards for marking when a process of struggle has produced constitutional norms worthy of judicial enforcement. On Ackerman's account, constitutional change requires clear proposal, prolonged deliberation, and super majoritarian consent. Article $\mathrm{V}$ provides a model of how to define these stages, one which may have remained salient for more than a half-century but which has been superseded by other processes.

Because Ackerman does not write on a blank slate, the power of this theory cannot be evaluated without placing it in the context of other recent efforts.

\section{CONSTITUTIONAL PROBLEMS AND CONSTITUTIONAL THEORY}

From the 1950 s to the early 1980 s constitutional theorists were obsessed with the question of whether the activism of the Warren Court could be legitimate in a polity whose democratic branches had the power that the New Deal had won recognition for. ${ }^{5}$ The range of diverse approaches taken by constitutional theorists of the last generation was held together at the center by the largely undiscussed consensus that judicial review was, as Alexander Bickel put it most evocatively, a "deviant institution" in American political culture. ${ }^{6}$

The solutions proposed by scholars to this so-called countermajoritarian difficulty are legion, but without too much damage they can be shoe-horned into three approaches. The first approach is to subordinate judicial review to the democratic ethos. The most successful such effort is probably John Hart Ely's Democracy and Distrust (1981), where he argued that democratic theory provided the master narrative to be imposed on the open-ended provisions of the Constitution.

A second approach subordinates democracy to fundamental rights thought to be embodied in the Constitution. A leading effort of this type

4. Youngstown Sheet \& Tube Co. v. Sawyer (the Steel Seizure Case), 343 U.S. 579 (1952), Jackson, J., concurring.

5. Martin Shapiro provides a cogent survey of how this obsession arose and its multigenerational effects, in "Fathers and Sons: The Court, the Commentators, and the Search for Values" in Vincent Blasi, ed., The Burger Court: The Counter-Revolution that Wasn't (New Haven, Conn.: Yale University Press, 1983).

6. Alexander Bickel, The Least Dangerous Branch: The Supreme Court at the Bar of Politics 18 (Cambridge, MA: Harvard University Press, 1962) ("Bickel, Least Dangerous Branch").

7. Ely, Democracy and Distrust (Cambridge, Mass.: Harvard University Press). 
is Ronald Dworkin's Taking Rights Seriously (1979). Fundamental rights theorists acknowledge the tension between democracy and judicial review but deny that democracy is an exclusive value in American political culture. Other values like liberty and equality may require majoritarian choices to be overruled.

A third approach has been to simply try to muddle through with judicial review relying on lawyerly virtues and a certain prudential circumspection constrained by the socialization of judges as "first-class lawyers." This was at times the view of Alexander Bickel and in some respects also that of Herbert Wechsler and Henry Hart. ${ }^{8}$ In some forms this approach can seem untheoretical altogether, but more recently historical figures like Edmund Burke have been mobilized to provide it with philosophical stature. ${ }^{9}$

During the 1980s constitutional theory underwent what might be described in retrospect as a "discursive" turn. The legitimacy problems were not solved, nor did they completely disappear, but they increasingly took second place to questions of constitutional language itself and of interpretation. In one sense the external problem of how to explain the relationship of courts to the other branches was replaced by an internal concern with technique. Philip Bobbitt's Constitutional Fate, ${ }^{10}$ published in 1982, marks this shift well. Bobbitt begins with the question of legitimacy, but it keeps getting pushed back behind an analysis of discursive strategies until in the end it is scarcely recognizable. ${ }^{11}$

Ackerman's perspective allows each of these master narratives of recent constitutional theory to be recast and reintegrated. With respect to the legitimacy of judicial review, Ackerman argues that there is no countermajoritarian difficulty. Judicial review represents not an alternative to democratic practice but another kind of democratic practice. The politics carried out by representative institutions and elected officials (the majoritarian process) is only one track of American politics-" "normal politics." The series of constitutional moments in Ackerman's history describe a second track of politics_-"higher lawmaking" or "constitutional" politics. When courts act to enforce the higher law created in such constitutional moments, they preserve the results of constitutional politics. ${ }^{12}$

8. Henry Hart \& Herbert Wechsler, The Federal Courts and the Federal System (Mineoloa, N.Y.: Foundation Press, 1953); Bickel, Least Dangerous Branch.

9. Paul Kahn, "Reason and Will in the Origins of American Constitutionalism," 98 Yale LJ. 449 (1989).

10. New Haven, Conn.: Yale University Press, 1982.

11. Another example of this trend is Ronald Dworkin. Compare his influential 1970s book, Taking Rights Seriously (Cambridge, Mass.: Harvard University Press, 1977), which concerned itself primarily with justifying judicial activism, and his major 1980 s contribution, Law's Empire (Cambridge, Mass.: Harvard University Press, 1988), which presents an argument for interpretive integrity in law. Dworkin did not abandon his claims about the fundamental legitimacy of the Warren Court precedents but shifted his attention to providing a more compelling account of "how" law works.

12. To say that courts are countermajoritarian because they sometimes block the re- 
Stated thus, this argument recalls the earliest, simplest, and presumably least credible theory of judicial review in all of constitutional law, John Marshall's argument in Marbury v. Madison ${ }^{13}$ that judicial review is simply the law of the principal (the people) trumping the law of the agents (their representatives). That vision is compelling for only the first day of most constitutional law classes, until the students are brought to notice the problem of who should decide that such a conflict of laws exists. In Marbury Marshall suggests that a judge need only lay statute against Constitution to know if a conflict is present, a position easily shredded. Indeed, in McCulloch v. Maryland ${ }^{14}$ Marshall contended that the Constitution was designed as a very general framework so that it could last for a long time and thus required a strong interpretive role for judges. After pointing out the contradictions between Marbury and McCulloch, most constitutional law teachers ultimately acknowledge the force of Marshall's view of judging without fully resolving the tension between the justification in Marbury and the model in McCulloch.

The constitutional narrative begun by Marshall depicts the sovereign people as first creating the Constitution and then largely disappearing, leaving its constitutional legacy to live only through an ever thickening patina of judicial commentary (legitimated by the theoretically possible but practically limited reappearance of the people through the amendment process). ${ }^{15}$ It is his rejection of this Marshallian cult that marks Ackerman's theory as one of radical departure.

In Ackerman's "Twilight Zone" the people, rather than the King, have two bodies. ${ }^{16}$ In their most frequent incarnation, they are the largely privately focused minions whose limited political attention span almost merits the sneering attitude of constitutional scholars (and political scientists in general). But on other occasions "we the people" become focused on some aspect of public life, mobilized by some social crisis or by the fierce and prolonged combat of our normal political institutions. On such occasions the people may appear in their other incarnation as sovereign founders.

Ackerman dubs as "dualism" the recognition that we have two politics and two modes in which the people participate in self-government corresponding to these two levels of politics: a representational mode of normal politics and a mode of something more like direct participation in

sults of normal politics is, in Ackerman's view, to unwittingly adopt a "monistic" view of American politics.

13. 5 U.S. (1 Cranch) 137 (1803).

14. 17 U.S. (4 Wheat.) 316 (1819).

15. While celebrating the dazzling achievement of the founding, most constitutional insiders can only shudder at the thought that a presumably shallow and irresponsible mass might really believe themselves the sovereigns of their land.

16. See Ernst H. Kantorowicz, The King's Two Bodies: A Study in Medieval Political Theory (Princeton, N.J.: Princeton University Press, 1957). 
constitutional politics. We would be back to Marshall if it were not for the fact that Ackerman recognizes that episodes of constitutional politics are regular if not frequent events in our history. Instead of judges interpreting constitutional law in the name of long-dead majorities, they may act to "preserve" the meanings established by the people in their most recent successful effort at constitutional politics (what Ackerman calls a constitutional moment). To avoid simply filling in their own meanings to broad constitutional language, judges must look to the process of constitutional politics. If they succeed, the majoritarian difficulty disappears.

Ironically "preservationist" review may in fact require that the court engage in actions that seem to make their legitimacy most vulnerable from the monist perspective. It is in transferring the logic of an episode of successful constitutional politics from the particular circumstances that inspired it (like slavery) to political practices seemingly removed (like state criminal trial procedures) that courts are most likely to antagonize the political branches. But it is precisely in such operations that the courts do what they do best in dualist logic, that is, translate a history of politics into law.

This leads Ackerman to a theory of constitutional interpretation that is markedly different from the largely literary approaches to interpretation that held sway since constitutional theory took the discursive turn into the 1980s. The analogy between the Constitution and works of literature is so powerful that one almost needs a theory to explain why constitutional scholars were able to avoid it for so long. When critical literary theory of interpretation emerged in academic law in the 1980s, it focused on the problem of how the Constitution's status as a text might provide constraints on the meanings discovered by its judicial interpreters. Scholars like Owen Fiss, Stanley Fish, and Ronald Dworkin have argued over whether texts need to be supplemented by rules of interpretive discipline, by commitments to integrity, or by a community of interpreters that is always already constrained. ${ }^{17}$ These various constitutional interpretations rely on the plausibility of such constraints to neutralize the legitimacy problems of the "countermajoritarian" difficulty. If judges can be shown to be constrained by the logic of interpretive practice, they will be less vulnerable to the accusation of substituting their own value judgments for those of the people.

While these theorists of interpretation envision judges as recollecting our constitutional history as the life saga of a coherent and, in some versions, attractive political subject, ${ }^{18}$ Ackerman directs judges to consider

17. Owen Fiss, "Objectivity and Interpretation," 34 Stan. L. Rev. 739 (1986); Stanley Fish, Doing What Comes Naturally: Change, Rhetoric, and the Practice of Theory in Literary and Legal Studies (Durham, N.C.: Duke University Press, 1989); Ronald Dworkin, A Matter of Principle (Cambridge, Mass: : Harvard University Press, 1985).

18. This can mean the subjectivity of the framers, as it does for the largely conservative 
the often antagonistic logic of our successive regime changes. From this perspective a constitutional moment like Reconstruction demands the wholesale redaction of whole parts of the Federalist Constitution. When judges resolve a case that raises issues of how two constitutional moments can be integrated, there is no guarantee in advance that the resulting synthesis will produce a subject that is coherent, let alone attractive. The act of interpretation is less one of sympathetic reconstruction than one of structural analysis (more on that later).

This does not mean that doctrine itself must be incoherent. Good preservationist judges on Ackerman's account seek to find principled ways of reconciling the objectives of different constitutional moments by emphasizing the particularistic or general character of each in relation to each other. Thus Ackerman suggests that a traditionally demonized Supreme Court opinion like The Slaughterhouse Cases, ${ }^{19}$ in which the Court declined to give a broad reading to the first section of the Fourteenth Amendment, in fact represented a principled effort to synthesize the new constitutional moment of Reconstruction with the legal structure created by the original Federalist constitutional moment. The work of synthesis will inevitably depend a great deal on the position of the judge relative to different moments. The Court that decided Slaughterhouse, on Ackerman's account, tended to particularize the aims of the Reconstruction moment that they had just lived through and subordinate them to the Federalist constitutional tradition in which they had developed as mature legal thinkers.

Unlike Dworkin, who wants judges to create as attractive as possible a picture of the political community, Ackerman expects judges to preserve the good, the bad, and the ugly. Part of what it means to preserve the constitutional moments achieved by earlier generations is to preserve their limits. For judges to rationalize constitutional doctrine into an attractive and coherent whole in the face of the contradictions and tensions that further history has revealed would be to usurp the role of the people. Indeed, the very unattractiveness and incoherence of law that may result from the work of a Court which insists on preserving the logic of earlier constitutional moments within its limits, in the face of pressure for change, is a critical stimulus for the people to mobilize and make new higher law. This permits Ackerman to perform an astounding reversal of common perception (worthy of Rod Serling at his best) revealing dreaded constitutional monsters, like Lochner v. New York, ${ }^{20}$ to be long-lost role models.

scholars whose slogan is "original intent," but it can also mean the most attractive reconstruction of our shared history as it does for liberals like Ronald Dworkin and Sanford Levinson.

19. 83 U.S. (16 Wall.) 36 (1873).

20. 198 U.S. 45 (1905), holding a New York regulation of the hours of labor unconstitutional. 


\section{ONE, TWO, THREE, MANY CONSTITUTIONAL MOMENTS}

A serious question which must be put to Ackerman's "dualism" is whether American political development can be appropriately fitted into the simple binary opposition Ackerman depicts between normal and constitutional politics. There are really two questions here. Do our politics come in two, and only two, kinds? Does the model of occasional but large transformative moments fit with our history?

One could accept the dualist idea that there is a profound difference between normal and constitutional politics but contend, as Frank Michelman does, that they are both present all the time. ${ }^{21}$ Rather than erupting in great episodic crises, constitutional politics might be ongoing, emerging constantly along all the lines of exclusion and domination in society. One could also imagine that there are great episodic crises in American politics, regime changes, but that these take place among the institutions of normal politics with no alteration in the basic structure of these institutions or the interests they may reflect, a perspective which much of the political science literature in American political development shares.

Ackerman himself suggests that the three great constitutional moments he has identified do not tower above an otherwise flat landscape; instead they are peaks in a mountain range composed of other lesser moments (at 98-99). In particular he identifies a number of specific movements that initiated processes of higher law politics but ultimately faltered, becoming "failed constitutional moments," among them the populists of the 1890 s, McCarthyism in the 1950 s, the civil rights movement of the 1950 s and 1960s, and the antiwar movement of the 1960s, and most recently (and somewhat prematurely I might add) the conservative "Reagan Revolution" of the 1980s (at 111-13).

If we accept Ackerman's schema, we are not forced to deny the effects of these lesser moments of constitutional politics. Presumably they may lay the groundwork for later successful constitutional moments by putting people on notice of the degree to which the basic political community is threatened from a particular angle and by generating proposals for change that continue to percolate in the public. Populism, for example, can be seen as both raising the danger which the new corporate economy posed to the security of the population and contributing to the New Deal. Failed moments also may clarify what is still most vital in the regime formed during the most recent constitutional moment.

Ackerman's dualist picture of American political development will undoubtedly be clarified when he completes two further volumes of this

21. Frank Michelman, "Law's Republic," 97 Yale L.J. 1493 (1988). 
project, one which will explore the middle republic put in place by the Reconstruction constitutional moment and running through the 1920s, and the other which will explore the modern republic initiated by the New Deal and persisting (if shakily) through the 1980s. But from the outline sketched in this first volume there are episodes of constitutional significance missing that reveal another less democratic dimension to our constitutional politics. These do not undermine the theory of constitutional moments, but they do suggest that some of the triumphant boosterism of We the People may be misplaced. Two examples will suffice to make the point.

The first is the so-called redemption of the South. Ackerman credits the Radical Republicans as the critical vanguard in rearranging the constitutional structure during Reconstruction by dramatically reducing federalism and forging a new level of national citizenship and power. He pays little attention to the successful white Southern resistance to the practices of Reconstruction that forced a profound redefinition of Republican objectives and ultimately of the constitutional form of the middle republic. The Redeemers succeeded in violently smashing the apparatus of state Republican party governments while negotiating a modus vivendi with northern capitalists and their representatives in the northern Republican party. ${ }^{22}$ The South they governed in the late 19th century was opened up to economic development, while its politics remained closely controlled by a traditional leadership class. At a minimum the Redeemers must be seen as achieving a special status for the South as a "distinct society" within the new constitutional order of the Union. I would argue that they achieved a more profound revision of the Reconstruction constitutional moment. The mixture the Redeemers embodied of authoritarian politics and procorporate economic policy seems characteristic of the middle republic nationally. ${ }^{23}$

The second episode I have in mind is the formation of the national security state during the 1940s and 1950s. ${ }^{24}$ Ackerman credits Franklin Roosevelt and the New Deal Democrats with once again reformulating our constitutional structure during the 1930s, but he treats the distinctive process of state formation around national defense as merely a permutation of the basic system put in place by the New Deal of strong presidential government (at 107-8).

This does not go far enough in recognizing the constitutional signifi-

22. See generally C. Vann Woodward, Origins of the New South, 1877-1913 (Baton Rouge: Louisiana State University Press, 1951), and Eric Foner, Reconstruction: America's Unfinished Revolution, 1863-1877 (New York: Harper \& Row, 1988).

23. See Alan Trachtenburg, The Incorporation of America: Culture and Society in the Guilded Age (New York: Hill \& Wang, 1982).

24. See Marcus Raskin, Essays of a Citizen: From National Security State to Democracy (Armonk, N.Y.: M. E. Sharpe, 1991). 
cance of anticommunism and the Cold War. ${ }^{25}$ The national security state constructed in the late 1940s and expanded in the 1950s continued the process of state building at the national level and the aggrandizement of the executive branch that Roosevelt had undertaken. The National Security Act of 1947 which created the Central Intelligence Agency and the National Security Agency deserves to be seen as at least quasi-constitutional. ${ }^{26}$ The structure it set in place transformed the operation of the executive branch and the roles of both Congress and the courts.

However, in contrast to the highly visible and widely debated New Deal economic program, the formation of a national security state was undertaken largely in secret. In contrast to the dramatic electoral contests over the New Deal, on which Ackerman rests much of his argument for the democratic nature of constitutional change, the Cold War ceased to be a significant issue of controversy between the major parties after 1948 . From Truman's reelection to the McGovern campaign of 1972, the basic commitment to global containment of communism and the massive distortions in domestic government that financing and administering such an enterprise required were never put before the American people for debate or decision. ${ }^{27}$ Both parties have likewise shared such a total commitment to anticommunism that not only has the nature of the communist threat been unavailable for discussion but significant developments that might have been generated by the New Deal state in the 1950s and 1960s like national health insurance and full employment policies have been virtually excluded from serious discussion until the present.

Perhaps my "Twilight Zone" analogy is inapposite after all. For while Rod Serling aimed at revealing the sinister implications hiding in the selfcongratulatory affluence of early 1960s America, Bruce Ackerman seems committed to a story that is unambiguously positive. Ackerman would probably argue that the two episodes in American political development I have mentioned fall short of constitutional moments but represent transformations that were limited to specific regions or domains of national life. Even if that is true, I have tried to sketch some reasons why we might view them as affecting the larger constitutional structure in profound wayswhich brings us back to the question of whether it makes sense to assume such a significant dichotomy in political life.

The question cannot be solved in abstract but only in the task of making sense of the complex history of our institutions which we might

25. To his credit Ackerman recognizes the significance of anticommunism as popular movement, something which has been significantly underappreciated in our constitutional history.

26. Harold Hongju Koh, The National Security Constitution: Sharing Power after the IranContra Affair 69 (New Haven, Conn.: Yale University Press, 1990).

27. If one treats McGovern as an anomaly (or part of the failed constitutional moment of the New Left), the period of Cold War government continues virtually to the present. 
expect from Ackerman's further volumes. In the meantime it seems noteworthy that the two episodes I have discussed constitute more conservative and less democratic processes of state building in America and as a result are doubtless less attractive to Ackerman's avowedly liberal social vision. It might be possible that these represent the constitutional moments of another less hallowed covenant in American politics of secret governments, conspiracies, assassinations, and coups d'état that has had its own discoverers from Charles Beard to Oliver Stone. ${ }^{28}$ It seems to me, however, that a more dialectical treatment of the constitutional moments Ackerman has focused on would serve us better than adding a new "dark" star to his political solar system.

Each moment, after all, is the result not only of the successful vanguard groups that seek to create a constitutional moment but also the resistance of groups who while unable to prevent change have nevertheless prevented the transformation from going further. The social forces that galvanized the Reconstruction Republicans also mobilized counterrevolutionary forces in both sections of the country that sought to find ways of channeling and eventually dissipating the Reconstruction effort. The massive electoral victories achieved by Roosevelt also inspired his opponents to seek ways of undermining the growth of the Democratic party and achieving a new ideological basis for attracting non-elite support. The first objective was achieved by legislation that sapped organized labor's growth (which had mobilized millions of workers to vote for the Democrats). ${ }^{29}$ The second was achieved by the anticommunist thetoric which Republican politicians from McCarthy to Reagan have used to good result in capturing working-class support.

Taking this seriously gives us a somewhat different picture than one where "We the People" periodically reemerge to redefine ourselves. Ackerman sees our history as the periodic efforts of the people to break through the structures created in one democratic process into another democratic process. Yet democratic forces have not been the only ones to influence our institutions. In my own lifetime the political leaders most capable of achieving a constitutional moment for the New Left, Martin Luther King and Robert Kennedy, were eliminated with gunshots in the year that brought Richard Nixon to the presidency and began a phase of conservative constitutional initiative.

28. See William Hofstadter, The Paranoid Style in American Politics, and Other Essays (New York: Knopf, 1965).

29. See Thomas Geoghegan, Which Side Are You on: Trying to Be for Labor When It's Flat on Its Back (New York: Knopf, 1991). 


\section{YOU DON'T NEED A WEATHERMAN TO KNOW WHICH WAY THE WIND BLOWS: JUDICIAL REVIEW AND CONSTITUTIONAL POLITICS}

Ackerman's theory reaches a long way toward a general theory of American politics, but it remains linked to its roots in academic constitutional law and to the multigenerational concern by legal academics with supporting a strong role for judicial review. From this perspective Ackerman's dualism is attractive because of the relative clarity it brings to the judicial role. Other theorists have argued that interpretive method can guide judicial power. In Ronald Dworkin's influential account, the judge must provide a coherent interpretation of all our significant past constitutional choices (judicial and otherwise), a task he acknowledges to be Herculean. ${ }^{30}$ Ackerman's theory at first glance offers a less daunting task, because a judge only has to locate the constitutional moment and go with it.

In brilliant readings of officially discredited decisions like The Slaughterhouse Cases, ${ }^{31}$ The Income Tax Cases, ${ }^{32}$ and modern classics like Brown ข. Board of Education ${ }^{33}$ and Griswold v. Connecticut, ${ }^{34}$ Ackerman suggests that judges engage in a process of synthesizing the three constitutional moments he identifies. A case would be decided first by analyzing which moments the constitutional question involved. Some cases are presumably solvable in light of only one moment, but most difficult ones involve synthesizing the constitutional politics of two constitutional moments, or even three. The Connecticut statute in Griswold, for example, required the Court to analyze the role of the federalist Constitution's personal liberties in the light of the post-New Deal role of the state (Ackerman at 156).

If Ackerman's method seems more objective, or at least easier to explain, than Dworkin's, it is not simply that a three-chapter chain novel is easier to work with than a longer one; the nature of the interpretive project is fundamentally different. Despite his avowed commitment to "buy American" 35 when it comes to social and political theory Ackerman's ap1988).

30. Ronald Dworkin, Law's Empire (Cambridge, Mass.: Harvard University Press,

31. 83 U.S. (16 Wall.) 36 (1873), declining to find that a state monopoly for animal slaughtering in New Orleans violated the Fourteenth Amendment.

32. Pollock v. Farmers' Loan \& Trust Co., 157 U.S. 429 (1895), striking down the income tax as unconstitutional.

33. 347 U.S. 483 (1954).

34. 381 U.S. 479 (1965), striking down a Connecticut law against dissemination of birth control information.

35. Ackerman at 11. Unless he wants to become the Pat Buchanan of academic law, Ackerman must concede that the relevance of social theories to understanding our Constitution must hinge on something more than the nationality of the author. Presumably he 
proach bears a strong resemblance to the structuralist social science so popular in Europe during the $1960 \mathrm{~s}^{36}$

Structuralist approaches analyze social practices to discern the formal operational structures assumed to be underlying and which can logically generate the empirically visible features. Structuralists have typically imagined "structures" to be composed of binary oppositions generally expressible as rules. In structural anthropology, for example, marital practices may be reduced to a formal structure of kinship (exogenous vs. endogenous, matrilineal vs. patrilineal). The specific practices of courtship, the ideology of what makes a good marriage, and its social functions may change historically, but they continue to reproduce the same structure. Likewise structural linguistics looks through the speech practices of a particular community to the generative rules that define a language.

Ackerman's method of reading constitutional history shares much in common with structural method. ${ }^{37}$ In his account, what we experience as our constitutional history can be generated from a structure of embedded binary oppositions. The most general opposition is that between normal and constitutional politics. Everything in Ackerman's account depends on knowing whether you are in one or the other. Binary structures are operative as well in the transformations of one to the other. While each constitutional moment may involve quite different causes and strategies, on Ackerman's account it must pass through a set of formal phases-signaling, proposal making, mobilized determination-which either do or do not take place.

I am not arguing that Ackerman has adopted structuralism in a thoroughgoing way. He remains interested in the historical specifics of constitutional change rather than treating the formal structure exclusively. There appears to be room in his history for agency and contingency to make a difference, and for structures themselves to possibly alter as the result of purposive action. But the structural elements in his approach are

might be pleased by the fact that the structuralist theorists I will be analogizing to him and the poststructuralist theorists I will be recommending are largely French and thus emerge from a nationality with a long interactive relationship to our own Revolution. In that case he could replace the trace of antiforeigner sentiment in this book (with its reactionary lineage) with an opposition to the anglophilia of American establishment academics (a progressive tradition I would heartily join him in).

36. There were American versions as well. Indeed during a panel presentation at the American Political Science Association annual meetings in Washington, D.C., in August 1991, Ackerman cited one of the most significant examples of American structuralism, Chomsky's linguistics, as an analogue to his constitutional theory.

37. This should be distinguished from the way we often speak of structuralism in constitutional theory. The structural theory of the Constitution developed by Charles Black uses the larger purposes of constitutional government as guides to interpreting its openended clauses. Structuralism in this sense is widely influential in almost all contemporary constitutional theories, including Ackerman's. See Charles Black, Structure and Relationship in Constitutional Law (Baton Rouge: Louisiana State University Press, 1969). 
critical to seeing why it is not simply the paint-by-numbers version of "law as integrity."

Ronald Dworkin, and other proponents of the view that laws involve the deep self-interpretation of the political community, study the constitutional moments of the past for clues to the self-definition of an underlying subjectivity. Dworkin's judge finds in our past political decisions the imprints of a coherent personality. Ackerman's judge searches for what we might call a grammar of political behavior established by a moment of constitutional transformation. Even the process of interpretation, of synthesizing constitutional moments to resolve a case, is described by Ackerman as a matter of deploying formal and binary rules. ${ }^{38}$

Noticing the differences between hermeneutic and structuralist approaches toward interpretation reveals how Ackerman's theory can be distinguished from other recent efforts. ${ }^{39}$ Failing to appreciate the structuralism in Ackerman's theory, Frank Michelman criticizes Ackerman for sharing with Robert Bork the view that judicial review must, if it is to be legitimate, consist in a "translation of directions uttered in the past by someone else." 40 Michelman is right that Ackerman's approach is inherently backward looking but wrong in assuming that Ackerman is like Bork in attempting to actualize the framers' understanding. In fact, Bork, Dworkin, and Michelman himself might be seen as sharing a commitment to the view that law is the "institutional manifestation of the political community's existence and identity as such." 41 In contrast, Ackerman is interested in revealing the underlying rules of engagement created by momentous constitutional restructurings. Successful constitutional moments require a conscious ratification, but what is being ratified is itself a kind of grammar of political action rather than specific outcomes.

There are considerable benefits from seeing the Constitution in this way. By moving away from historically constituted "meaning" as the linchpin of interpretation, one can make sense of the wide gap between the self-conception of a generation and the institutional structures they created. Since Brown v. Board of Education, the Court has been severely criticized for finding in the Fourteenth Amendment constraints on the government's treatment of race that the framing generation did not endorse. Indeed, the Reconstruction generation witnessed an almost blind-

38. Ackerman suggests that judges faced with deciding a legal question that involves synthesizing the products of two constitutional moments often (and properly) proceed by reducing one to a particularistic concern while reading the other as a broader structure of principle. This choice is not arbitrary; rather, judges tend to particularize the constitutional moment closest to their own lived experience. See Ackerman at 96.

39. For a useful summary of the contrast between hermeneutics and structuralism in recent Continental social theory see Hubert L. Dreyfus \& Paul Rabinow, Michel Foucault: Beyond Hermeneutics and Structuralism (Chicago: University of Chicago Press, 1982).

40. Michelman, 97 Yale L.J. at 1522 (cited in nore 21).

41. Id. at 1514. 
ingly fast shift in the presumptive politics of race. In less than a decade the debate went from the continuance of slavery to the right of black men to vote and govern. How, then, are we to say just what they ratified with respect to race? The preservationist judge escapes this question by focusing on the formal rules for engagement. He reads Brown as combining Reconstruction's concern that people not be prejudiced in public life on account of race with the New Deal's expansion of the public. Nothing in that interpretation turns on whether the framers of the Fourteenth Amendment intended to forbid segregation or viewed African Americans as fully equal to those with European heritage.

The great weakness of Ackerman's preservationist interpretation is, not surprisingly, the same problem that haunts structuralist social theory: its emphasis on formal elements leans on an awfully thin version of history. Even the Federalist constitutional moment, which is highlighted in this volume (as Reconstruction and the New Deal are to be in the later ones), is reduced by Ackerman to a number of formal rules of political engagement. We get virtually nothing about the social, economic, or political circumstances of the Revolution or the framing period. Focusing on formal structures is attractive jurisprudentially for the same reasons it is attractive in social theory-it gets you out of the messy task of talking about agency, motivation, meaning-but if the failings of the structural method in the social sciences are predictive, it will not be possible to remain as disengaged from history as Ackerman currently is.

If this cross-disciplinary analogy is at all useful, it may follow that Ackerman's project would be stronger if it abandoned the emphasis on structural analysis in favor of poststructuralist theories of practice like those of Pierre Bourdieu, Michel Foucault, Michel de Certeau, bell hooks, and Donna Haraway. ${ }^{42}$ In interpreting the constitutional moment wrought by Reconstruction, for example, a poststructuralist approach would emphasize the historically specific political practice of Reconstruction itself. From the latter perspective Reconstruction involves the deployment and testing of new strategies, new technologies of power, new social practices, rather than simply principles or formal rules of engagement. The Reconstruction Republicans did more than draft amendments. They deployed new administrative techniques like the Freedman's Bureaus, widened the

42. Pierre Bourdieu, Outline of a Theory of Practice (Cambridge: Cambridge University Press, 1977); Michel Foucaule, Discipline and Punish: The Birth of the Prison (New York: Harper \& Row, 1977); Michel de Certeau, Heterologies: Discourse on the Other (Minneapolis: University of Minnesota Press, 1986); bell hooks, Yearning: Race, Gender, and Cultural Politics (Boston: South End Press, 1990); Donna Haraway, Simians, Cyborgs, and Women: The Reinvention of Nature (London: Rourledge, 1991). Work influenced by poststructuralism is already being pursued in American legal thought. See the essays in Robert Post, ed., Law and the Order of Culture (Berkeley: University of California Press, 1990), and Texas Law Review Editors, Symposium: "Beyond Critique: Law, Culture, and the Politics of Form," 69 Texas L. Rev. 1881 (1991). 
availability of federal justice through the civil rights acts, and deployed military forces as an arm of policy without a bona fide threat of insurrection. Once on the table, these practices would alter the way courts have tended to see such supposedly intrusive measures as affirmative action or busing.

At the same time, any move in this direction threatens to remove the distance that separates judges (and their law professor shadows) from founders, citizens, and other kinds of actors in the constitutional system. ${ }^{43}$ For example, Ackerman argues persuasively that judges following his preservationist strategy will not be cast in a role of amending the Constitution, for they will merely deploy formal rules to determine whether the people have in fact done so. Thus while he argues that amendments need not follow the procedures of article $\mathrm{V}$ of the U.S. Constitution, they do follow a formal and predictable rule. ${ }^{44}$ It is this immunity that would have to be abandoned in a poststructuralist version of Ackerman's theory, leaving courts as exposed to the ambiguity and risk in constitutional change as are other actors. Once we are in the domain of practices, judges who interpret the Constitution cannot know for sure whether they will be perceived as preserving the living core of American politics or snuffing out forms of law and life. 45

\section{STOP MAKING SENSE: THE DEGRADATION OF CONSTITUTIONAL POLITICS}

One way in which Ackerman is already moving away from structuralism is in acknowledging that the dualist metastructure of American politics could change as we cease to recognize the difference between normal and constitutional politics. Indeed, as the book celebrates the unique contribution that dualism makes to constitutional government, he looks on the possibility of its degradation as a particularly sinister possibility in the present.

Dualism has on Ackerman's account been organized in several different forms. The assembly-centered system of constitutional politics inscribed in article $\mathrm{V}$ of the Constitution tended toward realization in constitutional amendments proposed by Congress or the states, and ratified ultimately by the popular assemblies of the states. The Reconstruction amendments strained this model on Ackerman's account by excluding the southern states from the ratification process. A presidencycentered system that began to emerge as early as Andrew Johnson's ill-

43. For Michelman, founders and citizens are the most important positions in our Republican political culture and judges must be both.

44. For the contrary view see Michelman, 97 Yale LJ. at 1522.

45. Robert Cover, "Forward: Nomos and Narrative," 97 Harv. L. Rev. 4 (1983). 
fated presidency but came into its own with Franklin Roosevelt has found its major medium for working constitutional moments in struggles with the Supreme Court, and its major method of writing constitutional transformation in Supreme Court opinions and Supreme Court appointments.

The model of the Roosevelt presidency stands for the proposition that the president can lead successful constitutional moments, but Ackerman raises important concerns about the new modern form of dualism. As presidents since Roosevelt act more and more as if constantly under a mandate for profound change, it becomes difficult to distinguish critical transformational choices from normal ones. This can lead to an obliteration of the distinction between normal and constitutional politics.

While reliance on judicial appointments to demarcate and institutionalize a process of constitutional politics may have been an acceptable procedural form for a president like Roosevelt whose personal popularity was matched by a constitutionally informed public and a solidly supportive Congress, it has worn less well for President Reagan. Reagan's technically impressive electoral campaigns avoided focus on constitutional issues altogether. Indeed, it was on this agenda, including opposition to abortion and retrenchment of civil rights, that his electoral coalition was most vulnerable to splitting between social conservatives and yuppies. ${ }^{46}$

Reagan's election victories may not provide the foundation for constitutional politics that Ackerman would judge as worthy, but they raise questions about the underlying dynamics of the public's involvement in normal and constitutional politics about which dualists and others cannot be sanguine. ${ }^{47}$ Later volumes may correct this, but the current sketch pays little attention to the huge role now played by the electronic media and its dominance through that of image politics. Can the signaling process that Ackerman identifies as central to constitutional politics cut through the white noise of sound bites and attack ads? ${ }^{48}$

46. Without these prerequisites the Reagan fight to reshape the Court takes on the appearance of a constitutional coup d'état rather than a constitutional moment. Indeed, we may conclude in the near future that the politics of the Reagan era, which sought to transform the structure of government by packing the court and loading the deficit to the point of paralyzing the operation of the federal government, was the least democratic transformation of the century.

47. To prevent the modern higher law-making system from getting stuck on judicial appointments, Ackerman (at 54) proposes the possibility of a more formal role for the president in proposing constitutional amendments during the second term to be voted on in national referendum to be held in conjunction with the next presidential election. But given the pathologies of the electoral process that have distorted the presidency-centered model of constitutional politics, it is unclear that such plebiscites would generate any better outcomes.

48. Ackerman's dualism helps makes this problem visible. Since traditional "monist" political science has long treated the people as marginal to most of politics, it is not surprising that the degeneration of political discourse was of little concern. From a dualist perspective this development takes on a more sinister character since the failures of "We the People" cannot be made up for by elites. 
Ackerman's qualifiedly optimistic analysis is based largely on the unsuccessful Bork nomination. ${ }^{49}$ The episode suggested both that people recognized the difference between normal and constitutional politics even in the specialized setting of judicial appointment (where every choice could appear to be a constitutional choice) and a rejection of Reagan's constitutional assault on the New Deal welfare state (in Ackerman's framework the people recognized that they were being faced with a constitutional moment and rejected the proposed change). But the important question that is left hanging in the book is what happens when, despite the absence of a mandate, the president succeeds in packing the Court with the complicity of a spineless opposition party unsure of what to stand for.

This analysis helps make sense of the bitter battle over Clarence Thomas and his narrow margin of victory. During the last phase of that process, and since, members of both political parties have attacked the "process" as out of control. Yet, after reading Ackerman, that is just what we should expect of a political fight that is actually channeling the tensions of constitutional politics. What needs to be addressed is not the process but the capacity of the parties, especially the pathetic Democratic party, to recognize and participate in higher constitution-making politics. Despite the successful mobilization against Bork, the Democrats in the Thomas fight seemed utterly incapable of signaling to people that a constitutional politics was at hand. Their only hope in the end was that the white noise of electronic media would blanket Thomas in a blizzard of bad images. The Republicans, as it turned out, are far more adept at managing such politics.

Whether Ackerman's theory of judgment can find a way to distinguish the constitutional legacy of a packed court from that of any other kind is a problem. If, as now seems imminent, a series of transformational opinions wipes out much of the Warren/Burger Court legacies, what likelihood is there that the new precedents will be weakened by the inadequacies in the pedigree of their constitutional politics? Does Ackerman really have confidence that future judges will look at those new Rehnquist Court precedents and see them as less legitimate than the late 1930s about-face because they lacked a pivotal election?

An even more disturbing question is whether our current system of constitutional politics is capable of generating the dialectical tension necessary for further constitutional evolution along the dualist path. This is a question that might be most fruitfully explored by political scientists studying the presidency, elections, and the dynamics of parties. One of the

49. The recent abortion decision, Casey v. Population Planning Center (1992), may suggest that the Reagan and Bush appointments have failed to produce a doctrinal transformation of the magnitude of 1934-44. It seems too early to tell. Clarence Thomas is perhaps the most ideological appointment yet. 


\section{LAW AND SOCLAL INQUIRY}

most important contributions of Ackerman's book may be precisely in bringing constitutional politics back into the study of politics where it has been marginalized for a long time now.

\section{CONCLUSION}

Bruce Ackerman's book raises many more insights and problems than have been addressed in this review essay. Big projects are vulnerable in all kinds of ways. Ackerman's project does something much more than provide a big target; it remaps a continent of constitutional theory and history that should generate disagreements but also new research projects and new theories.

This intervention comes at the right time. For the last generation our constitutional theorizing has been dominated by efforts to defend or attack the expansive jurisprudence of the Warren and early Burger Courts. As the current Supreme Court has moved further and further from those landmarks, there has been a certain sterility to constitutional discourse. We need to rethink constitutionalism without the obsessive focus on justifying or negating Supreme Court decisions. We the People, whatever its flaws, provides a new and much more adequate point of departure for that thinking. 